\title{
Arabic Across the Curriculum in a Bilingual Gulf University
}

\author{
Nagwa Hedaiat \\ Zayed University, Dubai Discuss this paper online at http://groups.yahoo.com/LTHE/
}

\begin{abstract}
Arabic Across the Curriculum is a broad language support program at Zayed University in the UAE, which has stimulated discussion on several issues concerning Arabic language support in the Arab world in general and in the Gulf area in particular. These issues can be summed up in the following questions: Why do we need to teach Arabic to native Arabic-speaking students? How will Arabic language proficiency help students in their academic and future careers? Which Arabic language skills should we teach native speakers in higher education, and how? What means of assessment and what criteria might be helpful to Arabic programs and instructors?
\end{abstract}

\section{Introduction}

ZU graduates are widely expected to be among the future leaders in the Gulf Region; and it is important to consider what kind of philosophy and teaching approach is appropriate to this goal. The main language of instruction at $\mathrm{ZU}$ is English, and it has adopted Western academic standards. There is much emphasis on proficiency in the English language as well as on information technology at Zayed University, but because $\mathrm{ZU}$ is a national university in the UAE, the Arabic language also has a significant place in its mission. The Minister of Higher Education and President of the University, His Excellency Shaikh Nahayan Al Nahayan, summarized his vision of a combined national and global identity in the following words:

Zayed University will gain a distinct identity as a world class university if we produce graduates who are proficient in both Arabic and English, and skilled in the use of information technology (ZU Convocation, 2002).

The Arabic language as the heritage language of the students is the essence of their cultural and national identity, while English, as the most widely spoken world language, seems to be equally important in the educational philosophy at ZU. Needless to say, a student who studies all subjects in English and is proficient in Arabic, including using Arabic in IT, has access to a much wider range of resources and authentic cultural knowledge than a student who has only one language through which the learning process can be attempted and achieved.

It is often assumed that as these students are native speakers of Arabic, they do not have a need for a special academic program to help them learn their own mother tongue. However, the use of Arabic or any other language for purposes of academic learning or research (what Cummins (1979) calls Cognitive Academic Language Proficiency) is quite different from the Basic Interpersonal Communication Skills (Cummins, 1979) of everyday interaction. In the case of both first language (L1) and 
second language (L2), learning occurs along a continuum between subconscious, automatic processes and conscious, analytic processes fostered by language instruction (Ellis, 1988). Therefore, it is no wonder that we see in most countries college L1 courses such as English 101 in the USA or UK, or equivalent French or German L1 college courses to develop native speakers' use of their mother tongue for academic purposes. Zayed University's Arabic Across the Curriculum (AAC) program is an Arabic language support program which aims to serve a similar goal in an institution that has an L2 (English) as its main language of instruction.

In this paper I will describe the nascent AAC program at Zayed University, which supports Arabic as a first language for Arab students in a mainly English-medium university. I will consider the following issues: Why do these native speakers need this sort of language support and what are the potential benefits for students and for their society in terms of academic and professional skills? Which variety of Arabic and which language skills should be emphasized in this language training? How can these skills be developed and assessed within a mainly English-medium university?

\section{The Arabic of UAE freshman students}

In this part of the paper I will outline the general L1 situation of the ZU students when they join the university, as it appears from their placement/ diagnostic test.

In any language which is used in both speech and writing, there are differences between the spoken and written language, and these have been linked with levels of cognitive complexity (Olson, 1977); in the case of Arabic the differences between the spoken and written language are very pronounced. The vernacular language of the Gulf area in general shares its major features of pronunciation, vocabulary and grammar with the Bedouin Arabic variety which exists, with some regional variations, in Sinai (De Jong, 2000), in the north western desert of Egypt (Matar, 1981), Saudi Arabia (Abboud, 1979), northern Palestine and northern Jordan (Sakarna, 2002). Both Ferguson (1959) and Badawi (1985) refer to a phenomenon that is known in language study as diglossia, i.e., the difference between the vernacular variety, which they refer to as "Low language" and Modern Standard Arabic (MSA) to which they refer to as the "High language". The dialect, or vernacular variety, is mainly a spoken language that varies widely along geographical and socio-economic lines from one Arab region to another and from one community to another within the same region; it is the informal daily life language use. The dialect in a region is the means of most oral communication and oral literature, and is occasionally used in written contexts such as novels, short stories, advertisements, cartoons and personal letters (Al Batal, 1993). On the other hand, MSA is mainly written, literary and formal, serving as the official language of all Arab countries; and it is learned mainly through formal instruction. It is the standard language of the educated Arab in formal speaking situations and in almost all writing and reading.

This diglossic situation is clear in the Gulf as it is in other Arab regions, although there is interplay between the Standard and the vernacular varieties in the language of almost all educated Arabs (Hijazi, 1998). There is actually a scale of formality (Badawi, 1971) from the poetic Arabic used in the Qur'aan, through Modern Standard Arabic (the language of literature, media and formal communication) to the various regional vernaculars. Modern Standard Arabic is taught in schools, and is the language of all educated Arabs from the Gulf to the Ocean; it is also the language of instruction of ZU's AAC program. However, any proficient educated 
Arab should be able to move up and down the scale between vernacular and Modern Standard Arabic, depending on the situation, subject and his/her interlocutor (Hedayet, 1993).

The vernacular Gulf Arabic spoken by ZU students differs from MSA in its pronunciation, grammar and vocabulary (Qafisheh, 1977, Sakarna, 2002 De Jong, 2000, Holes, 1983 and others). In terms of pronunciation, Gulf Arabic is characterized by the pronunciation of "ik" (as in kick) as "ich" (as in "which"), guttural "q" as " $g$ ", and "j" (as in "joke") as "y" (as in "you"). One example is the difference between Modern Standard Arabic kayfa halik? (how are you? to a female), and the Gulf Arabic equivalent kaif halich?. Another example is the translation of the simple English sentence They came: a non-Gulf Arab listening to UAE vernacular will hear yom, which could be interpreted as yoom (a day) or as om (a mother). Such differences may impede communication and may create confusion and misunderstanding on the part of a non-Gulf Arab. In students' writing, the differences in pronunciation habits lead to widespread mis-spelling of words, which affect comprehensibility and give an unprofessional impression.

Gulf Arabic tends to use different forms of words from Modern Standard Arabic, e.g. mashkoor (thank you - literally you are thanked) rather than the Standard shookran. Nzain is a very common 'filler' expression in Gulf Arabic, meaning well or OK; most other Arabs will wait for the rest of the sentence, which to them will be a halfsentence meaning if it was good..., and needing to be completed. Numerous such examples occur not only in students' speech but also in their writing.

Some vocabulary common in UAE Arabic is borrowed from other languages, despite the existence of Arabic equivalents used by Arabs from outside the Region. In oral and sometimes in written forms, especially on street signs and boards, Hindi, Urdu and now modern English vocabulary as well have become common. In everyday situations, one will constantly hear words like seeda (Hindi for straight on), khordeh (Urdu for small change), or English body for a woman's upper garment. This, along with the other differences referred to above, may cause an educated non-Gulf Arab to hesitate in understanding what s/he hears, and may impede or distort communication between native speakers of Arabic.

It is also important to remember that most $\mathrm{ZU}$ students come to Arabic instruction in AAC after spending one or two years in intensive English study in the English Language Center, which tends to influence the students' Arabic speaking as well as their writing proficiency. For example, Arabic sentences may be phrased with English word order - this reinforces tendencies of Bedouin Arabic, and gives an awkward impression in written Arabic.

Still another factor that must be taken into consideration in examining of the students' use of MSA is the somewhat negative attitude of the majority towards learning the Standard language. In observing some elementary and secondary school Arabic language classrooms as a co-supervisor of the College of Education interns, it was clear that the pupils' attitude was not very positive in these classes. This is no doubt partly due to the unmotivating teaching methodologies used in such classes: many Arabic language teachers, viewing the Arabic language as sacred (because it was the language through which the word of God was revealed in alQur'aan) have been misled into thinking that the traditional methods for teaching this language are sacred as well. However, the traditional emphasis on reading, memorization and grammar can no longer continue to be effective or appealing to 
learners in an age of information technology where performance-based language skills are needed. The challenge of putting performance-based, functional and communicative teaching methods into practice seems to be a general one in the Arab World, for we still do not have enough trained teachers who apply modern methods of language teaching, as well as in other subjects, in their classrooms (UNIDO, 2003).

\section{The Aims of an Arabic Support Program}

If, following Hymes (1967), communicative competence is taken to comprise text cohesion and coherence, rhetorical organization, choice of register and other aspects of language, one might doubt that the majority of secondary school graduates in any culture could be fully proficient upon joining their institution of higher education: freshman students' writing, in any language, tends to lack cohesion, coherence and a sustained ease in articulating, developing or communicating ideas. The Report of the National Commission on Writing in Americas' Schools and Colleges, in April 2003, discusses problems in writing competency in the USA and calls for a "writing revolution" in order to revive the "Neglected R" (National Commission on Writing, 2003). The report explains that despite the importance of the writing skill, there is not much time given to it in different curricula.

ZU students may be expected to have acquired reasonable receptive skills (listening and reading) by the time they join the university. However, in writing ZU students, like their American counterparts, need help in tackling new genres in their first language - with the added complexities of the language situation in the Arab world. In terms of Badawi's (1971) classification, the Arabic of a secondary school graduate does not normally exceed the level of a semi-educated Arab. In an entry test conducted with students entering the university in 2002 and 2003, almost all the students' writing lacked coherence, cohesion, and correct orthography, let alone correct citation or other higher level skills. Although more research is needed in this area, the designers of the AAC program at ZU believe that the students' productive skills (writing and speaking) should be the focus of L1 support, in order to enable the students to cope with academic standards in their native language.

Writing is seen as an act of discovery where the students exercise their minds and can analyze, synthesize, apply what they comprehend in their own words. In this process, other disciplines come to share the benefits. The ZU AAC program supports students in writing short and long assignments expressing interpretive reactions to information received in class or from their reading, to facilitate internalization and retention (Emig, 1997). Training the students to reflect critically in an organized and persuasive way is working at the higher level of the students' thinking: they will constantly be correcting, modifying and evaluating what they think of, with a view to communicating it to an audience (Curtain and Pesola, 1988). Students use internet search engines and other information technologies in researching and presenting their written work, and are expected to enhance their ability to write from the time they enter the program until they graduate from the university.

There is an increasing demand all over the world now for persons proficient in Arabic, whether in schools, universities, media, diplomatic corps, FBI, CIA, or transcontinental corporations, and proficiency in Arabic will open work opportunities 
for our students whether here in the Gulf Region or in any other place in today's world. Bilingualism is a personal and societal asset, which AAC at ZU tries to support its students to enjoy. Self-confidence as a part of personal development is very much related to one's competence at negotiating and exercising one's communicative oral and written skills to realize personal and professional aspirations.

If we really hope that our graduates will make a difference in their community and lead future generations to a better life for all, we should enable them to strengthen their productive language skills. One of the first characteristics of leadership is to articulate ideas, develop themes, organize thoughts and above all raise enthusiasm among her or his work group to foster shared beliefs and sense of community and cooperation (Waters et al, 2004). Almost all of these qualities depend to some extent on communicative competence in speaking and writing.

The designers of AAC program at ZU saw an urgent need to train the students in the productive language skills, i.e., writing and speaking in order to develop their interpersonal, interpretive and presentational communicative competencies. This was the idea behind setting up a program that empowers the students' productive skills without detracting from the mainstream English language content courses at the university, and which ultimately has benefits for other academic disciplines.

\section{What Is Arabic Across the Curriculum at ZU?}

$A A C$ is an innovative language program which started at Zayed University in September 2001. It provides support for students' first language through the different disciplines of the university. The learning outcomes of AAC at ZU hope that at the end of this L1 support the student will be able to:

1. Employ appropriate language and style in academic writing

2. Articulate ideas and elaborate on them clearly and accurately

3. Develop coherent and well-organized discourse

4. Use linguistic syntax correctly

5. Write summaries, short essays, and commentaries related to subjects studied

6. Use basic referencing conventions for a scholarly source

7. Use a range of vocabulary appropriate to the subject matter

8. Develop critical acumen, deeper understanding of texts' nuance and aesthetics

9. Read a variety of Arabic texts and analyze them

10. Mastery of oral and written presentational skills

(Gamal, 2001, 2003).

In the fall semester of 2003, the Arabic Language Center (ALC) offered a separate course specifically in Arabic Composition, which ZU students now study as a requirement immediately after they finish their intensive English language program. One may consider this composition course as L1 across the curriculum in the sense that it is part of a core curriculum which all students in different disciplines must study. 
AAC provision is designed along the lines of Writing Across the Curriculum (WAC) which is a pedagogical movement that started in the $80 \mathrm{~s}$ as a response to a perceived deficiency in literacy among college students as the Purdue university online writing lab site indicates. (See also Bazerman and Russell, 1994). As part of their WAC programs, some institutions in the USA have online materials about incorporating writing into content courses; and these institutions have a variety of language support to their students and faculty as well. George Mason, Harvard, Pittsburg and University of Purdue are some institutions which implement this language across the curriculum pedagogy in their institutions.

The same reason that motivated the above pedagogical movement is also what made the Writing Commission of the Americas Schools \& Colleges declare a writing "Revolution" in its report a year ago. (National Commission on Writing, 2003). In this report all the country responsible people from congressmen, government officers to university administrators and instructors were asked to help in their own ways and decision making to improve the writing skill of the nation. France example is not less motivating for the necessity of always improving the nation's writing skill to the extent that one sees functional and literary French writing support is for the public to make use of (http://www.admi.net/epv/). In this approach the skill of writing is emphasized in this language pedagogical instruction because it is viewed to open the students up to "the pleasure of exercising their minds in ways that grinding on facts, details, and information never will: it is viewed as an act of discovery more than a way of knowing" (Allen, 2003). In line with this approach, the Arabic composition course at ZU uses reading texts of a controversial nature to help develop students' vocabulary and style as well as to develop critical thinking and meta-cognition skills in writing and speaking.

Information and Communication Technology is an integral part of this, as of other courses at ZU. The students make use of PowerPoint or other software in practising their presentational oral skills. There is a shared course folder used by all the instructors who teach the composition course. Each Arabic language instructor has his or her own Blackboard course folder on the university intranet where his or her students can access all the materials that this particular instructor displays for his/her course whether the syllabus, reading texts for discussions, handouts, language exercises, PowerPoint presentations etc. Instructors also use PowerPoint and other software to help their students internalize certain language ideas or writing styles, or to brainstorm a topic in the classroom. There is a constant exchange of e-mail between the Arabic instructor and the students. In the final capstone projects, where Arabic support is sometimes given, the students often have creative ideas using all sorts of software, including making their own project on a CD, designing a web site for a school or an association, designing a magazine or a journal etc. Arabic instructors supervise these projects and are familiar with the same technological tools. ZU students are required to use the Internet in seeking information for the different writing and discussion topics as well as for their long assignments and projects.

In addition to this separate Arabic course, Arabic language support can be integrated into the English-medium content courses, using three main approaches:

a) In some cases oral or written assignments in Arabic are planned in as an integral component of content courses taught in English. These assignments are set in collaboration with the content course instructor, and may consist of a paragraph, a 
summary, an outline, a questionnaire, an abstract, an essay, a report, a research paper, or a group or individual oral presentation. One, two or three Arabic assignments are thus integrated in the content course in agreement with the course instructor wherever s/he sees fit in her or his syllabus.

b) Certain courses or pieces of material which are closely related to Arabic and/or Arab culture may be be taught jointly by one Arab and one Western faculty member. This approach has been used in some courses in the College of Family Sciences: Special Topics in Family Sciences, Sources of Family Sciences and Methods of Research in Family Sciences. The Arabic instructor may teach one of the three course hours each week, or may teach half the semester and the English content course instructor the other half.

c) Certain courses have been taught entirely in Arabic. These include the Education courses Methods of Teaching Arabic, Research Methods in Family Science, and Islamic Studies.

During the academic year 2002-2003, I worked with Zayed University's College of Family Sciences and the College of Education on the Abu Dhabi campus. My job was to provide Arabic language support for the internship program in both colleges, including language supervision and consultation of the interns in both colleges. I had 18 interns in each college, and part of my job was to go on regular school visits and class observations with the Education interns. I also paid visits to other work sites where the Family Sciences interns did their training: these included a women's social association, an autism center, a hospital, and a center for special needs people, where these interns were doing the practical part of their study before graduation.

Another part of my job was to provide language support and co-supervision for students in their Family Sciences capstone projects. In these projects the students were expected to synthesize and reconstruct the knowledge they have acquired through their studies in a creative final project of their own before graduation. Each student developed a thesis, for which she developed a questionnaire to be written in Arabic for field research, a letter of consent, and an abstract of her research; in most cases the final paper itself was written in English. My role included guiding students to resources in Arabic on their different topics and checking their final Arabic resources.

I supported a further eighteen students studying in the course Case-Based Study Assessment, in which each student was given a family case to analyze and assess. Another very interesting course was Individual and Family Assessment. The seventeen students on this course were given three different assignments, varying in length and in assessment objectives, which the (American) course instructor required to be written in Arabic (while the other assignments were in English). The total number of the students of these courses exceeded ninety; each of them wrote at least two drafts and a final writing of the required assignment in Arabic.

\section{Assessing Arabic L1 proficiency}

The Education students' writing included lesson plans and class materials/activities for young students in different subject areas in local elementary and secondary classes; all students also prepared a CV and in some cases also wrote Arabic reflections on their experiences during internship. Students in the internship program, capstone projects as well as the case-based study assessment students 
had to give a final oral presentation about their experiences and research. Conferencing with the students, sometimes in groups of three or four, and training during that time in Standard Arabic conversation were helpful as a preparation for their final oral presentations so that it would become easier. Two Arabic instructors attended these final oral presentations and assessed the students according to criteria given to students at the beginning of the course. Afterwards oral feedback was given to the student to help her understand her weaknesses and strengths.

Each student was required to keep a portfolio in hard copy form, and hand in her word-processed assignments to me either by sending it as an attachment through $\mathrm{ZU}$ e-mail or as a hard copy in case discussion over the assignment was needed. Correction was done using correction codes agreed upon and distributed to the students at the beginning of the course. Two drafts were written in most cases before the final paper was handed in to me.

The final assessment of these students' proficiency skills in writing and speaking was based on several sources of information: the portfolio which included all the drafts and the final writings of the student, as well as the oral presentation and the final written report or research project. I kept a file during the course for each student, including comments and reflective journal entries in addition to assessments according to the guidelines and specifications of each course - distributed to the students at the beginning of the course. In addition to the above, a holistic assessment and a proficiency rating (similar to guidelines of the American Council on the Teaching of Foreign Languages - ACTFL) was taken into consideration in terms of the language context, content, and language tasks/ functions, focusing on the highest proficiency levels in order to be appropriate to L1 learners.

My holistic assessment of students' oral and written proficiency drew on my ACTFL training as an oral proficiency interviewer in Arabic as a Foreign Language. The ACTFL proficiency assessment criteria in foreign languages started in the 1980 s and were last revised in 1999; they were first applied to oral proficiency and later to the other three language skills of reading, writing and listening comprehension. These assessment criteria were applied first to European languages and later to less commonly taught languages. Arabic was included in 1987 (Allen, 1987). There are four major levels of proficiency: Superior, Advanced, Intermediate and Novice. The latter two levels are divided again into three minor levels (Low, Mid and High). The Advanced level is divided into Advanced and Advanced Plus. The Superior is a single top level that corresponds to a native speaker language level (See Appendix 1). The advantage of these criteria is that they facilitate holistic assessment, in terms of clearly described ordered series of levels. They focus on what users can do: the language content they can comfortably work with and the contexts or practical situations in which they can exercise these functions. The proficiency of a language learner is thus the sustained level of functioning or competency at a certain level (ACTFL Preliminary Guidelines, 2001).

The ACTFL assessment is a proficiency rating and not a grade of achievement. It is also obvious that proficiency as described by ACTFL early proponents had claimed is far less absolute and broad (Liskin-Gasparro, J. E., 2003). But if the goal of instruction is to have students reason, interact, and learn through the language medium, even in early levels of instruction, then the approaches and activities that enhance processes of cognition and communication naturally fall under the rubric of proficiency (Liskin-Gasparro, 2003). The rating scale summarizing statements about 
functions and text types that characterize each of the levels provides a common frame of reference to describe achievement in a complex system in terms meaningful to all the different partners in or users of that system (North, 1993). Therefore, the present author suggests the use of L1 proficiency criteria rubrics that may help do the same in Arabic in higher education (see Appendix $2 \& 3$ ). It is for the instructors and program designers so that they can plan the curriculum and instructions along the number of courses or years of study they have so that at the end their students will be able to perform these tasks in the different contents and contexts needed. For each course or year there will be specific objectives or learning outcomes for which the student's achievement should be measured by grades. These rubrics can be transferred into grades on another sheet to be given to the administration, parents or students.

\section{Challenges}

There remain several challenges in developing an AAC program in $\mathrm{ZU}$, and probably in other universities in the Arab World.

Firstly, bilingual education is still new to higher education, not only in the Arab World but in general, and there is no close example or model on which to build. One of the results of this is that the program is not institutionalized yet; i.e., Arabic support could be given to a specific course in one campus and not on the other, and I may teach the capstone project students this semester and not in the following one. This depends on several elements, one of which is personal relations.

Secondly, Writing Across the Curriculum (WAC), the only precedent approach in teaching language through other disciplines in a university or college, usually uses the same language of instruction as other courses in that particular university or college. Therefore, there is much more understanding, awareness and perhaps positive coordination by the institution, and content instructors are more likely to see some benefit on their side for such language support.

Thirdly, Arabic is one of the less commonly taught languages; and therefore far less international research has been conducted on it, either as a first or as a second language, to exchange ideas and motivate educational methods. Only very recently, particularly in the last decade, have we begun to see serious research on Arabic as a foreign language, partly through the efforts of the American Association of the Teachers of Arabic (AATA); this will hopefully lead to more research in the area of teaching Arabic as a first language. Much research is needed in pedagogy and Arabic L1 acquisition. A major issue here is the testing and assessment issue of L1 in higher education. To date there are no specifications of the proficiency criteria according to which a native speaker of Arabic may be rated or assessed. The suggestion of this paper here is seen to be an attempt in this area.

Fourthly, many of the content course instructors are not so positive about AAC and feel that it takes time out of their courses, and that there is no direct benefit to their students which would help them in their courses. This in turn has its effect on the Arabic language instructors, who feel frustrated and anxious while offering their language support to the students of these instructors if they ever have the chance.

Fifthly, to develop the skill of writing in any language program, more time is probably needed to be able to reach the desired outcomes. Therefore, a lot of coordination is hoped for in order to realize the needed proficiency skills. 
Finally, because AAC is an unconventional Arabic language program some of the latest pedagogical methods such as the use of information technology, needs more development on the part of some instructors.

\section{Conclusion}

AAC is an active program at ZU where students' skills of speaking and writing in Standard Arabic are supported both in an Arabic composition course and within the other content courses in the different colleges of the university. Through varied speaking and writing activities in and out of class Arabic L1 skills are beginning to develop towards proficiency. There exists certain challenges such as the lack of time to work thoroughly on developing these skills, and attitudes of some faculty whereby AAC is viewed as taking time away from other, more "important", subjects. There is also a need for awareness of the importance of developing Arabic language proficiency of college students in general; otherwise, we will have new generations who lack skills of using language for analyzing, synthesizing and evaluating. One may see L1 communicative competency as the vehicle of personal and community development.

One possible direction for future work is to use some sort of modified language rubric that combines the basic idea of proficiency guidelines (as developed by ACTFL) for measuring task/function, content, context and type of discourse, with the characteristics of the educated native speaker as described by Badawi (1971). These ideas need to be shared with other educators in the Arabic language field in the hope of opening this important issue of Arabic language education in its three dimensions - curriculum, instruction and assessment - in our colleges and universities in the Gulf and in the Arab world in general.

\section{References}

Abboud, P. F. (1979). The Verb in Northern Najdi Arabic. Bulletin of the School of Oriental and African Studies 42 (3): 467-499. University of London.

ACTFL Preliminary Guidelines. (2001). A Revised Ed., ACTFL, Inc.

Al Batal, M. (1993). Issues in Teaching the Productive Skills in Arabic. In Al Batal, M. (Ed.). The Teaching of Arabic as a Foreign Language: Issues and Directions. Al'Arabiyya Monograph Series \# 2: 115-130.

Allen, R (1985). Arabic Proficiency Guidelines. Al-'Arabiyya. Journal of the American Association of Teachers of Arabic 18 (1\&2): 45-70.

Allen, R. (1989). ACTFL Proficiency Guidelines. Foreign Language Annals 22: 373391.

Allen, R. (2003). Expanding Writing's Role in Learning: Teacher Training Holds Key to Change. Curriculum Update, Association Supervision \& Curriculum Development: 1-8.

Badawi, E. (1971). mustawayaat al- 'arabiyya al-mu'aasira fi misr (Levels of Contemporary Arabic in Egypt). Cairo: dar al- ma'aarif.

Badawi, E. (1985). Educated Spoken Arabic: A problem in Teaching Arabic as a Foreign Language. In Jankowski, K.R. (Ed). Scientific and Humanistic Dimensions of language. John Benjamin Pub. Company, pp 15-22. 
Bazerman, C. \& Russell, D. (Eds., 1994). Landmark Essays on Writing Across the Curriculum. Davis, CA: Hermagoras Press.

Curtain, H. A. and Pesola, C. A. (1988). Languages and Children - Making the Match. Addison Wesley.

Cummins, J. (1979). Cognitive Academic Language Proficiency, Linguistic Interdependence, The Optimum Age Question, And Some Other Matters. Working Papers on Bilingualism 19: 197-205.

De Jong, R. (2000). A Grammar of the Bedouin Dialects of the Northern Sinai Littoral: Bridging the Linguistic Gap Between Eastern and Western Arab World. Leiden: Brill.

Emig, J. (1997). Writing as a Mode of Learning. College Composition and Communication 28: 122-128.

Ferguson, C. (1959). Diglossia. Word 15: 325-340.

Gamal, A. (2001). Arabic Language Center Operation Guidelines. Dubai: Zayed University.

Gamal, A. (2003). COL 130 Arabic Composition Course Syllabus. Dubai: Zayed University.

Hedayet, N. (1993). ACTFL Proficiency Interview and the Problem of CodeSwitching in Arabic as a Foreign Language. Conference Proceedings of the Association Internationale de Langues Linguistique. Holland, Amsterdam.

Hijazi, Mahmoud Fahmi. (1998). The Arabic Language in the Modern Age: Issues and Problems. Cairo, Qobaa Publishing House.

Hymes, D. (1967). Models of the Interaction of Language and Social Setting. Journal of Social Issues 23: 8-28.

Liskin-Gasparro, Judith E. (2003). The ACTFL Proficiency Guidelines \& the Oral Proficiency Interview: A Brief History \& Analysis of Their Survival. Foreign Language Annals 36 No. 4: 483-489.

Matar, A. (1981). " Lahjato I-badwi” in Arabic (Bedouin Vernacular Arabic). Dar alma'aarif, Cairo.

Olson, D. 1977. From Utterance to Text: The Bias of Language in Speech and Writing. Harvard Educational Review, 47:257-281.

Sakarna, Ahmad Khalaf. (2002). The Bedouin Dialect of Al- Zawaida Tribe, Southern Jordan. Al-'Arabiyya. Journal of the American Association of Teachers of Arabic (35): 61-86.

National Commission on Writing in America's Schools and Colleges. (2003). The Neglected "R": The Need for a Writing Revolution. Retrieved Feb. 15", 2004 from $<$ http://www.writingcommission.org>.

North, B. (1993). The Development of Descriptors on Scales of Language Proficiency. Washington, D.C.: National Foreign Language Center.

UNIDO Arab Human Development Report (2002, 2003). Arab Fund for Economic \& Social Development. Retrieved on Nov. 20th, 2003 from $<$ http//:www.undp.org/publications>. 
Waters, J. T., Marzano, R.J. and McNulty, B. (2004). Leadership That Sparks Learning. Education Leadership 61/7: 48-51.

\section{About the Author}

Nagwa Hedaiat gained her PhD from the University of Cairo, and now teaches Arabic Studies, Arabic as a Foreign Language and Arab-Islamic Civilization in the Arabic Language Center in Zayed University. Her research interests include curriculum development in Arabic as a Foreign Language and Arabic as a First Language. 


\section{Appendix: Assessment Instruments} ACTFL Proficiency Guidelines (Four Major Levels)

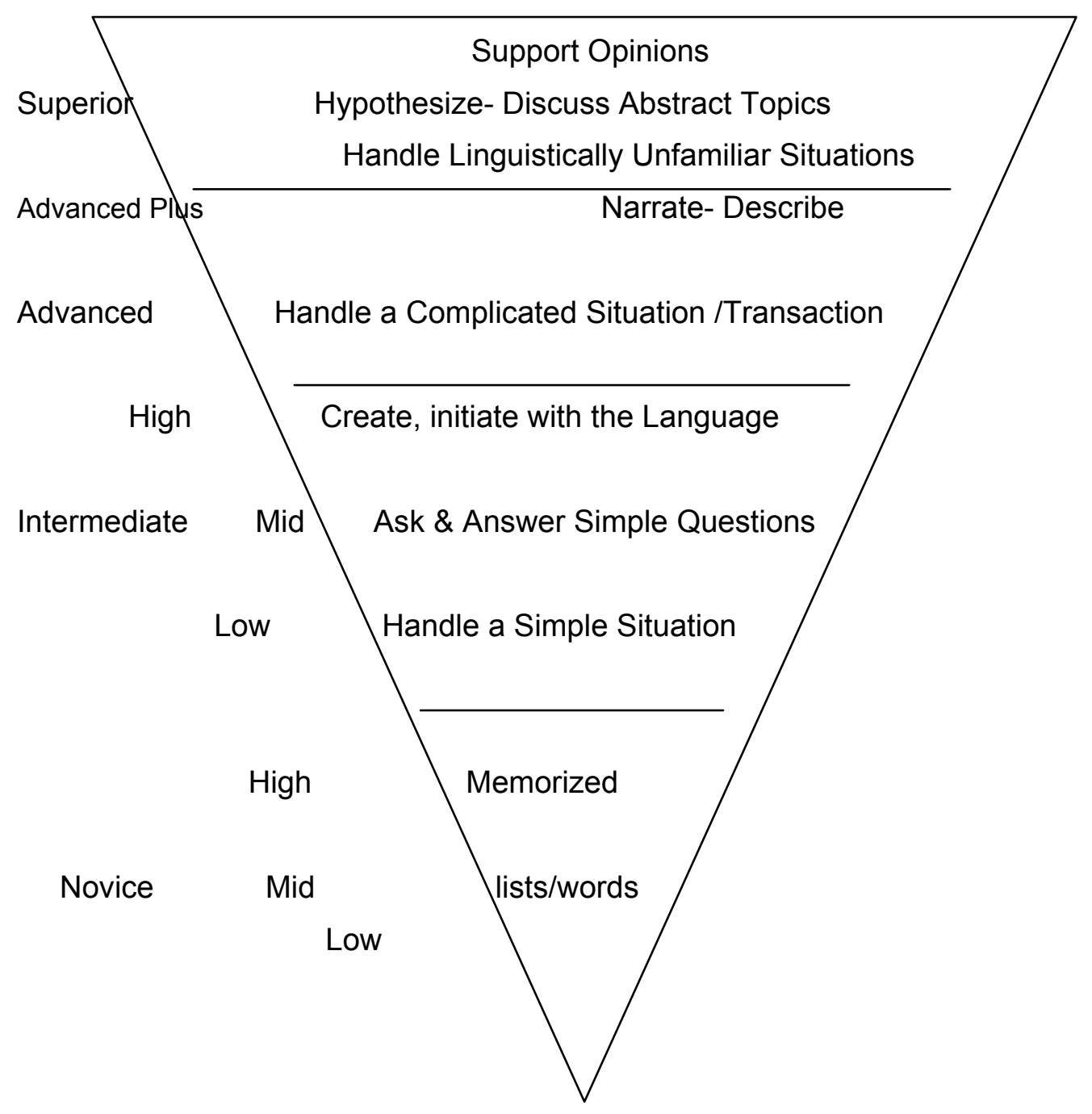


Appendix No. 2

\section{Criteria of Oral Proficiency in Standard Arabic Modified to L1 (Three Major levels)}

\begin{tabular}{|c|c|c|c|}
\hline $\begin{array}{l}\text { Standards } \\
\text { Criteria }\end{array}$ & Superior & Advanced & Intermediate \\
\hline $\begin{array}{l}\text { 4- Code switching } \\
\text { between SA \& } \\
\text { Emirati Coll. }\end{array}$ & $\begin{array}{l}\text { Consistently able to } \\
\text { engage in extended } \\
\text { conversation defending } \\
\text { opinions, hypothesize } \\
\text { and talk about abstracts } \\
\text { while promoting high } \\
\text { levels of audience } \\
\text { understanding. } \\
\text {-Able to talk in most } \\
\text { formal \& informal } \\
\text { contexts. } \\
\text { - Able to talk about a } \\
\text { wide range of public as } \\
\text { well as personal areas } \\
\text { of interest \& } \\
\text { specialization including } \\
\text { abstracts \& unfamiliar } \\
\text { topics. } \\
\text {-Can easily code } \\
\text { switch between SA } \\
\text { and Coll. in the } \\
\text { appropriate places. }\end{array}$ & $\begin{array}{l}\text {-Able to talk in all } \\
\text { informal situations \& } \\
\text { some formal situations } \\
\text {-Able to carry } \\
\text { conversation about } \\
\text { topics of realistic \& } \\
\text { materialistic topics of } \\
\text { public \& personal } \\
\text { interests (can express } \\
\text { opinion but not able to } \\
\text { persuade others) } \\
\text { Not consistently able } \\
\text { to code switch } \\
\text { between SA \& Coll. in } \\
\text { the appropriate } \\
\text { places. }\end{array}$ & $\begin{array}{l}\text { Often able to carry on } \\
\text { a simple face to face } \\
\text { conversation by asking } \\
\text { \& answering questions. } \\
\text { Audience } \\
\text { understanding is } \\
\text { superficial and of a } \\
\text { limited scope. } \\
\text { - Able to talk effect- } \\
\text { tively in some informal } \\
\text { transactional situations. } \\
\text {-Can talk about topics } \\
\text { related to the person of } \\
\text { the speaker or her /his } \\
\text { surrounding } \\
\text { environment. } \\
\text { Not usually able to } \\
\text { code switch between } \\
\text { SA \& Coll. In the } \\
\text { appropriate places. }\end{array}$ \\
\hline Accuracy & $\begin{array}{l}\text { Consistently precise \& } \\
\text { correct; the very few } \\
\text { errors do not influence } \\
\text { articulate } \\
\text { communication. }\end{array}$ & $\begin{array}{l}\text { Usually precise and the } \\
\text { errors in grammar, } \\
\text { choice of vocabulary } \\
\text { do not impede } \\
\text { understanding }\end{array}$ & $\begin{array}{l}\text { Often precise \& } \\
\text { correct but errors may } \\
\text { influence } \\
\text { communication }\end{array}$ \\
\hline Coherence \& Cohesion & $\begin{array}{l}\text { Consistently has } \\
\text { extended discourse that } \\
\text { is highly organized \& } \\
\text { well integrated. }\end{array}$ & $\begin{array}{l}\text { Usually speaks in well } \\
\text { organized paragraphs } \\
\text { that are well } \\
\text { integrated. }\end{array}$ & $\begin{array}{l}\text { Often speaks in form } \\
\text { of sentences or string } \\
\text { of sentences without } \\
\text { connectors or } \\
\text { integration. }\end{array}$ \\
\hline Audience Engagement & $\begin{array}{l}\text { Consistently engages } \\
\text { audience by } \\
\text { enthusiasm, tone of } \\
\text { voice, non-verbal } \\
\text { supports \& sharing of } \\
\text { thoughts and ideas, } \\
\text { using the appropriate } \\
\text { code switching of SA } \\
\text { \& Coll. }\end{array}$ & $\begin{array}{l}\text { Usually engages } \\
\text { audience by } \\
\text { enthusiasm, voice pitch } \\
\text { \& tone and sharing of } \\
\text { ideas, using the } \\
\text { appropriate code } \\
\text { switching of SA \& } \\
\text { Coll. }\end{array}$ & $\begin{array}{l}\text { Often engages } \\
\text { audience by verbal \& } \\
\text { non-verbal supports. } \\
\text { Not usually able to } \\
\text { code switch between } \\
\text { SA \& Coll. In the } \\
\text { appropriate places. }\end{array}$ \\
\hline Ethical Practices & $\begin{array}{l}\text { Consistently uses } \\
\text { ethical practices in the } \\
\text { acquisition, } \\
\text { manipulation \& } \\
\text { reporting of } \\
\text { information. }\end{array}$ & $\begin{array}{l}\text { Usually uses ethical } \\
\text { practices in the } \\
\text { acquisition, } \\
\text { manipulation and } \\
\text { reporting of } \\
\text { information. }\end{array}$ & $\begin{array}{l}\text { Often uses ethical } \\
\text { practices in the } \\
\text { acquisition, } \\
\text { manipulation \& } \\
\text { reporting of } \\
\text { information. }\end{array}$ \\
\hline
\end{tabular}


A native college graduate should be able to achieve one of the first two standards of the above rubric of oral proficiency, i.e., either Superior or Advanced; otherwise s/he is not proficient in Arabic L1 speaking.

Appendix No. 3

Criteria of Writing Proficiency in Arabic L1

\begin{tabular}{|c|c|c|c|}
\hline $\begin{array}{l}\text { Srandards } \\
\text { Criteria }\end{array}$ & Superior & Advanced & Intermediate \\
\hline $\begin{array}{l}\text { 1-Function } \\
\text { Communicative } \\
\text { Competency }\end{array}$ & $\begin{array}{l}\text { Consistently able to } \\
\text { communicate meaning } \\
\text { with ease and clarity. Can } \\
\text { support opinions, } \\
\text { hypothesize \& write about } \\
\text { abstract topics and express } \\
\text { linguistically unfamiliar } \\
\text { situations while promoting } \\
\text { a high level of audience } \\
\text { understanding. } \\
\text {-Able to write most } \\
\text { informal and formal types } \\
\text { of writing including } \\
\text { academic research papers } \\
\text { \& abstracts } \\
\text {-Able to express in writing } \\
\text { all personal public and } \\
\text { specialized topics } \\
\text { including unfamiliar ones. } \\
\text { (exceeds expectation) }\end{array}$ & $\begin{array}{l}\text { Usually able to } \\
\text { communicate meaning } \\
\text { clearly with some ease, } \\
\text { narrate, describe \& express } \\
\text { professional and unfamiliar } \\
\text { situations while promoting } \\
\text { high levels of audience } \\
\text { understanding. } \\
\text {-Usually able to write most } \\
\text { formal \& informal types of } \\
\text { writing including research } \\
\text { papers \& abstracts. } \\
\text {-Usually able to write about } \\
\text { a wide range of personal and } \\
\text { public as well as specialized } \\
\text { topics. } \\
\text { (meets expectations). }\end{array}$ & $\begin{array}{l}\text { Often communicates } \\
\text { meaning clearly \& with ease. } \\
\text { Often has a coherent } \\
\text { treatment of the topic with } \\
\text { clearly developed ideas in } \\
\text { some topics. The frequent } \\
\text { errors in orthography \& } \\
\text { language convention seldom } \\
\text { affect audience } \\
\text { understanding. } \\
\text {-Able to write about simple } \\
\text { and unprofessional situations. } \\
\text { - Often able to write about } \\
\text { personal and public and } \\
\text { specialized topics. }\end{array}$ \\
\hline Accuracy & $\begin{array}{l}\text { Consistently has a strong } \\
\text { control of syntax \& } \\
\text { morphology, a sound use } \\
\text { of complex sentences, a } \\
\text { superior use of vocabulary } \\
\text { and use of verb tenses, } \\
\text { appropriateness \& ease of } \\
\text { expressions use/ } \\
\text { orthography and writing } \\
\text { conventions are generally } \\
\text { correct. }\end{array}$ & $\begin{array}{l}\text { Usually has a strong control } \\
\text { of syntax \& morphology, a } \\
\text { sound use of complex } \\
\text { sentences, a superior use of } \\
\text { vocabulary and verb tenses, } \\
\text { appropriate use of } \\
\text { expressions/correct } \\
\text { orthography \& writing } \\
\text { conventions. }\end{array}$ & $\begin{array}{l}\text { Often has a strong control of } \\
\text { syntax \& morphology, a } \\
\text { sound use of complex } \\
\text { sentences, a good use of } \\
\text { vocabulary \& verb tenses, } \\
\text { appropriate use of } \\
\text { expressions/correct } \\
\text { orthography \& writing } \\
\text { conventions. }\end{array}$ \\
\hline $\begin{array}{l}\text { Coherence\& } \\
\text { Cohesion }\end{array}$ & $\begin{array}{l}\text { Consistently has a } \\
\text { coherent treatment of topic } \\
\text { \& clearly developed ideas } \\
\text { where transitional phrases } \\
\text { \& sentences well serve } \\
\text { writing cohesion. }\end{array}$ & $\begin{array}{l}\text { Usually has a coherent } \\
\text { treatment of topic \& clearly } \\
\text { developed ideas where } \\
\text { transitional phrases \& } \\
\text { sentences well serve writing } \\
\text { cohesion. }\end{array}$ & $\begin{array}{l}\text { Often has a coherent } \\
\text { treatment of a topic \& clearly } \\
\text { developed ideas where } \\
\text { transitional phrases \& } \\
\text { sentences well serve writing } \\
\text { cohesion. }\end{array}$ \\
\hline $\begin{array}{l}\text { Audience } \\
\text { Engagement }\end{array}$ & $\begin{array}{l}\text { Consistently engages } \\
\text { audience by innovative } \\
\text { ideas, enthusiasm \& } \\
\text { respect. }\end{array}$ & $\begin{array}{l}\text { Usually engages audience } \\
\text { by innovative ideas, } \\
\text { enthusiasm \& respect. }\end{array}$ & $\begin{array}{l}\text { Often engages audience by } \\
\text { innovative ideas, enthusiasm } \\
\& \text { respect. }\end{array}$ \\
\hline $\begin{array}{l}\text { Information } \\
\text { Technology }\end{array}$ & $\begin{array}{l}\text { Consistently able to } \\
\text { employ mediums to }\end{array}$ & $\begin{array}{l}\text { Usually able to employ } \\
\text { mediums to display content }\end{array}$ & $\begin{array}{l}\text { Often able to employ } \\
\text { mediums to display content to }\end{array}$ \\
\hline
\end{tabular}




\begin{tabular}{|l|l|l|l|}
\hline Competency & $\begin{array}{l}\text { display content to } \\
\text { effectively persuade target } \\
\text { audiences, and advance } \\
\text { quality of research. }\end{array}$ & $\begin{array}{l}\text { to effectively persuade } \\
\text { target audiences, and } \\
\text { advance quality of research. }\end{array}$ & $\begin{array}{l}\text { effectively persuade target } \\
\text { audiences, and advance } \\
\text { quality of research. }\end{array}$ \\
\hline Ethical Practices & $\begin{array}{l}\text { Consistently applies ethics } \\
\text { in acquiring, manipulating } \\
\text { and reporting information. }\end{array}$ & $\begin{array}{l}\text { Usually applies ethics in } \\
\text { acquiring, manipulating \& } \\
\text { reporting information. }\end{array}$ & $\begin{array}{l}\text { Often applies ethics in } \\
\text { acquiring, manipulating and } \\
\text { reporting information. }\end{array}$ \\
\hline
\end{tabular}

A native speaker college graduate should be able to achieve one of the first two standards of the above rubric of writing proficiency, i.e., either Superior or Advanced; otherwise s/he is not proficient in Arabic L1 writing. 